\title{
Implementation Of Maqasid Shari'ah In Islamic House Financing: A Study Of The Rights And Responsibilities Of Contracting Parties In Bai’ Bithaman Ajil And Musharakah Mutanaqisah
}

\author{
Rafidah Mohd Azli, Rohana Othman, Mardiyyah Sahri, Nooraslinda Abdul Aris, Roshayani Arshad, \\ Accounting Research Institute, Universiti Teknologi MARA, Malaysia \\ Abdul Razak Yaakob, \\ Business Consultancy of Islamic Banking and Finance Institute Malaysia (IBFIM), Malaysia
}

\begin{abstract}
The Maqasid-oriented approach in Islam demonstrates the Muslims commitment to uphold the authenticity of Islam as a religion and a complete way of life (ad-din). Maqasid Shari'ah is a transparent tool to outline and clarify the effective extent of the rights and responsibilities of the Mukallaf (servant of Allah) towards each other. Ignorance on Maqasid Shari'ah in Islamic business transactions, particularly for Islamic house financing led to misinterpretation, disruption, chaos, and trivial conflicts among the contracting parties. This paper discusses the implementation of Bai' Bithaman Ajil (BBA) and Musharakah Mutanaqisah (MM) Home Financing instruments as practiced in Malaysia using the method of Imam al Shatibi. This paper concluded that a sound understanding of the knowledge, goals, and objectives of the Shari'ah at every level of a contract involving parties to a sale and purchase in Islamic Home Financing would enable improvement in practice through ijtihad (collective decision or general consensus). The Maqasid Shari'ah (the objective of Islamic Jurispudence) is adequate to provide the appropriate vehicle and procedure for the fulfillment of rights and responsibilities of contracting parties, thereby eliminating all sorts of financial criminology in trading and business (Kamali, 2002).
\end{abstract}

Keywords: Maqasid Shari'ah; Islamic House Financing; Bai' Bithaman Ajil (BBA); Musharakah Mutanaqisah $(M M)$; Shari'ah-based house financing

\section{INTRODUCTION}

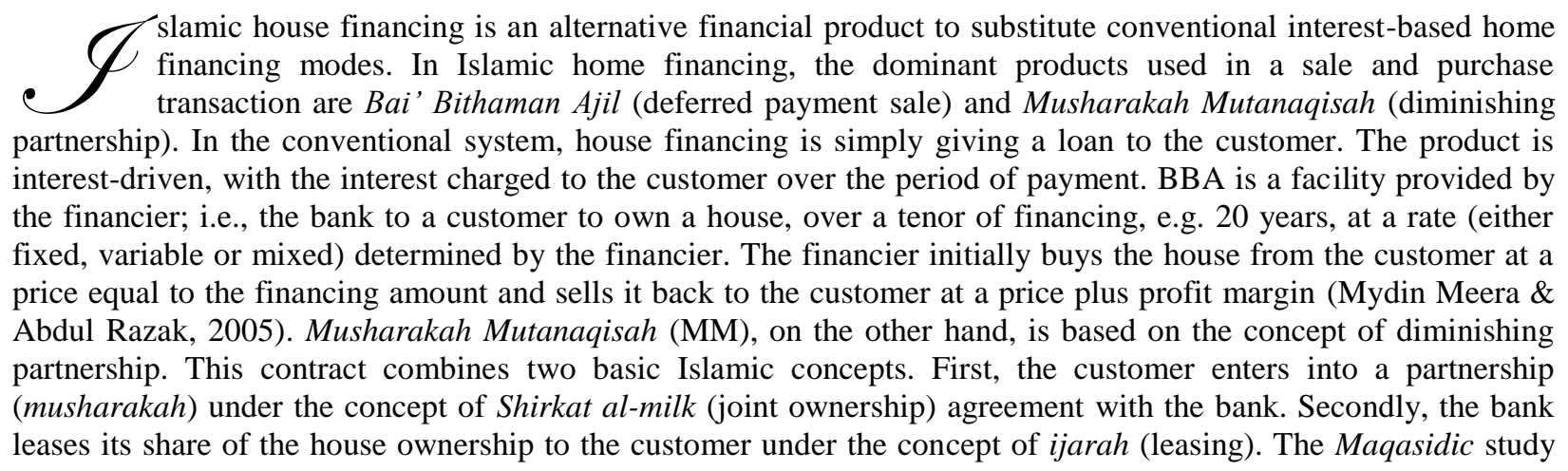


on these two different frameworks, BBA and MM, is essential to examine the effectiveness of the rights and responsibilities of contracting parties (Mydin Meera \& Abdul Razak, 2005).

To ease our understanding, look at Figures 1 and 2 and compare the concept of both agreements being practiced in Malaysia.

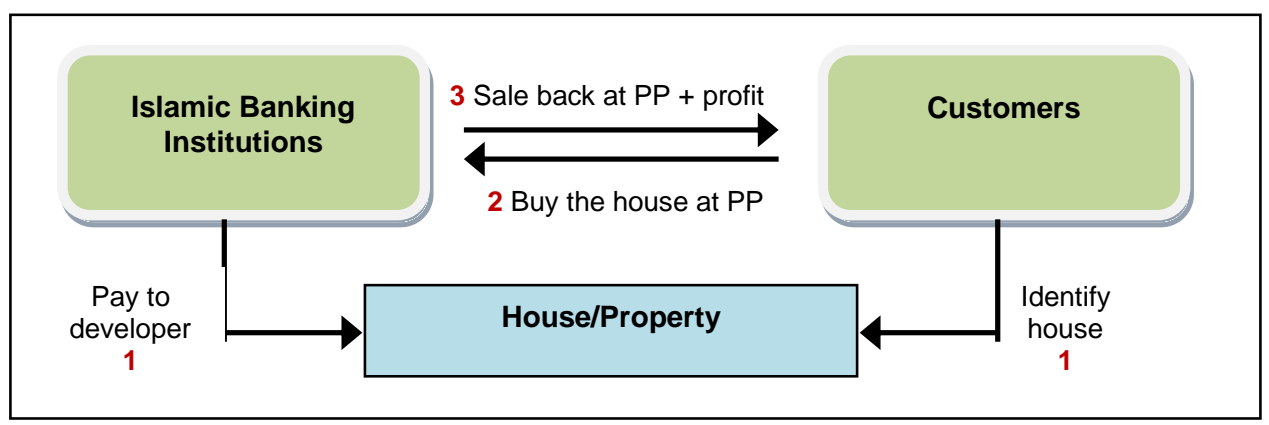

Figure 1: Structure of Bai’ Bithaman Ajil (BBA) House Financing

1. The customer identifies the property and normally pays $20 \%$ of the selling price and asks the bank to finance $80 \%$.

2. The customer then signs an agreement with the bank. The bank will buy the property from the customer at a price equal to the financing amount required. The bank will pay the remaining $80 \%$ to the developer.

3. The customer then agrees to buy back the asset at a price equal to the financing amount plus profit charged by the bank. The amount will be paid on deferred terms based on tenor agreed.

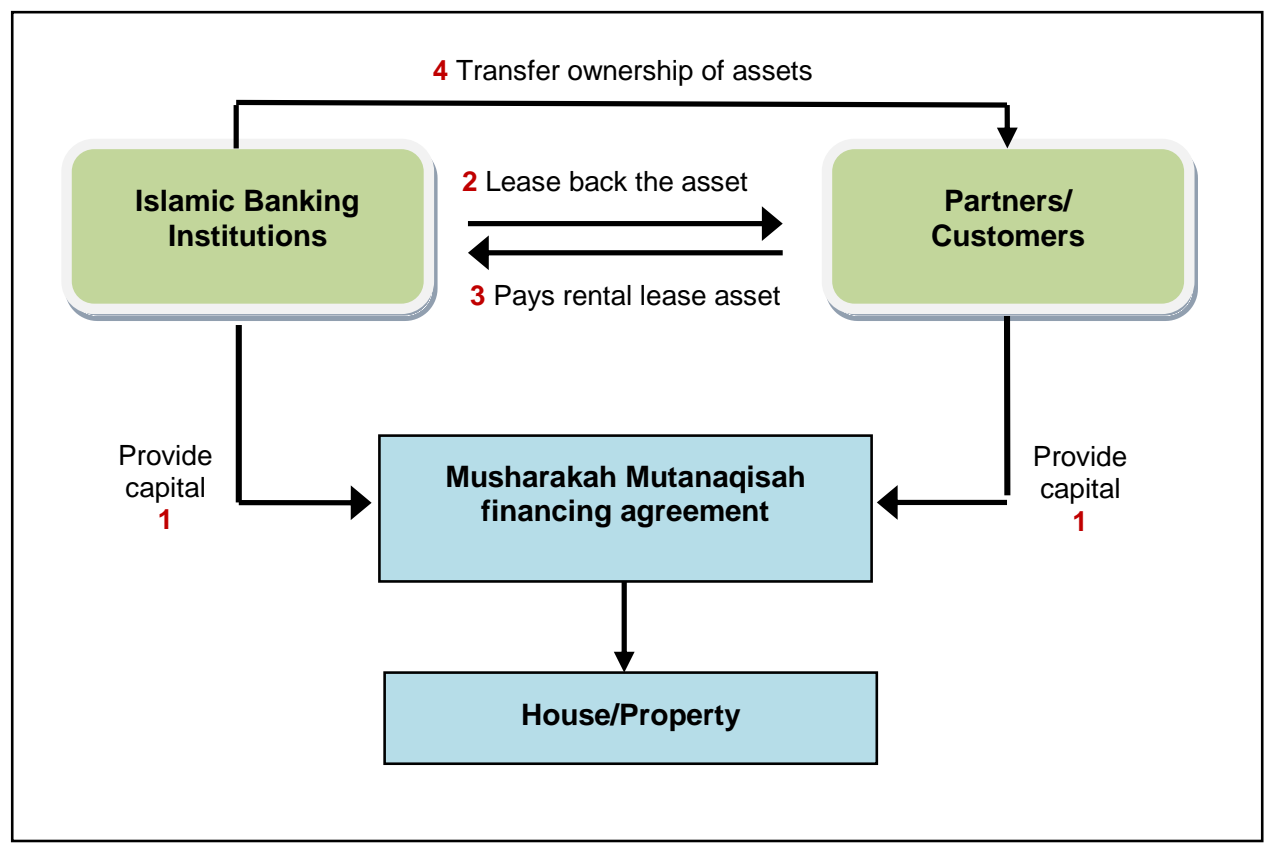

Figure 2: Structure of Musharakah Mutanaqisah (MM) House Financing 
1. The customer identifies the property and normally pays $20 \%$ of the selling price with $80 \%$ being financed by the bank. The customer and the bank will therefore own $20 \%$ and $80 \%$ of the property, respectively.

2. The customer then leases/uses the property.

3. To compensate the bank, the customer pays rent for the use of the bank's share of the property.

4. The bank's share of the property is divided into 20 units of $4 \%$ each (assuming the tenor is for 20 years). The customer promises to buy one unit each year for the next 20 years in the form of rental payment. Once the units have been fully owned by the customer, the property will be the customer's and the bank will have the profits.

Many researchers have highlighted the inconsistencies of the practice of BBA house financing in Malaysia in comparison with the principle of Maqasid Shari'ah (Mydin Meera \& Abdul Razak, 2005; Abdul Razak \& Md. Taib, 2008 and Md. Dahlan \& Syed Abdul Kader, 2009). The problem of ignorance of Maqasid Shari'ah elements or Maslahah aspects has been identified in BBA house financing compared to MM house financing. The ignorance of elements, such as Raf' al-Haraj (remove hardship) and Daf' al-Dharar (preventing harm), where the welfare of the people is left unprotected, especially in the case of abandoned houses, culminates into a possible criminal act when the transaction is conducted under an Islamic label.

Hence, a thorough understanding of Maqasid Shari'ah is crucial in view of the commitment of the bank as the seller and the customer as the buyer to uphold justice, brotherhood and social welfare. This will inevitably lead to a society where every member will cooperate with each other (Dusuki, 2008). In fact, the paradigm of Maqasid Shari'ah in BBA and MM deserve a relook and the role of Maslahah in the Shari'ah then can be confined to making ijtihad on a particular issue in the absence of a respective definitive text and to choosing the opinion that is believed to serve public interest (Dusuki, 2008).

This paper presents the outcome of a study on the rights and responsibilities of contracting parties in the house financing scheme under BBA and MM guided by the principle of Maqasid Shari'ah. Special emphasis is focused on the crucial impact of financial criminology; that is, the issue of abandoned housing projects in Malaysia.

The following sections will, in order, illustrate the fundamentals of Shari'ah and its objectives, the implication of rights and responsibilities of buyer and seller in Islam, the implementation of Maqasid Shari'ah by contracting parties in Islamic house financing, ignorance of Maqasid Shari'ah by contracting parties, critical issues, and finally, the conclusions.

\section{SHARI'AH AND ITS OBJECTIVES}

The application, flexibility and development of economic, business and worldly activities are embodied in the Shari'ah which is central to Islam's worldview. The Shari'ah covers all aspects of life - personal, social, political, economic and intellectual. These major areas of human life, as well as its major means of adjusting to change, cannot be separated or isolated from Islam's basic belief, values and objectives. In other words, the Shari'ah is a complete and integrated code of life encompassing all aspects of life, be it individual or social, both in this world and hereafter (Dusuki, 2008).

The Maqasid Shari'ah or objective of Shari'ah is part of the literature that deals with understanding of the Shari'ah. Every single Muslim needs to comprehend the Maqasid Shari'ah because this allows flexibility, dynamism and creativity in social and financial policy. According to Imam al-Ghazali (R.A.):

The objective of the Shari'ah is to promote the well-being of all mankind, which lies in safeguarding their faith (Deen), their human self (Nafs), their intellect (Aql), their posterity (Nasl) and their wealth (Mal). Whatever ensures the safeguard of these five serves public interest.

This crucial account of Maqasid Shari'ah shows that the philosophy of Shari'ah is directed toward benefiting the individual and community as well as protecting and facilitating every single aspect of the individual and society. The uppermost objective in the Shari'ah is to establish justice, eliminate prejudice, and alleviate hardship by promoting cooperation and mutual support (Dusuki, 2008). 
Maslahah sometimes connotes the same meaning as Maqasid. Maslahah means 'welfare, interest, or benefit'. Maslahah and manfa'ah are treated as synonyms. Maslahah in Muwafaqat, as defined by Dusuki (2008), is "a principle that concerns the subsistence of human life, the completion of livelihood, and the acquisition of what his/her emotional and intellectual qualities required by him/her." According to Imam al-Ghazali in his famous book al-Mustasfa, Maslahah is defined as "an expression for seeking benefit (Manfa'ah) or removing something harmful (Mudarra)". He then explained further that Maslahah is essentially the preservation of the objectives of Shari'ah which consist of five items: preservation of religion, life, intellectual, posterity and property. He also concludes by saying, "What assures the preservation of these five principles is Maslahah and whatever fails to preserve them is Mafsadah and its removal is Maslahah" (Al-Ghazali pp. 286-87).

The Maqasid Shari'ah contains stipulations to be applied in trading or sale and purchase contracts. The principle of Islamic corporate social responsibilities enshrined under Islamic guidance brings about a balance between individuals rights and their duties and responsibilities toward others. Social responsibility is not solely a duty of the government, but it is a duty of all members of the community. The responsibility includes corporations and business entities in trading transaction, operation and work process. Many scholars, among them, Kamali, M.Umar Chapra, Imran Nyazee, Michael Mumisa, Ziauddin Sardar and Wael Hallaq, view that Maslahah or Maqasid-based methodology could be used to derive new rulings from the Shari'ah, meet society's changing needs and solve contemporary problems related to business endeavours (Dusuki, 2008).

The Maqasid Shari'ah's approach can be the transparent method to establish an effective relationship among contracting parties in any Islamic trading, more so in the contract of sale and purchase. The relationship between contracting parties is clearly defined from the rights and responsibilities, thereby determining the validity of the contract or otherwise. In Islam, a contract is considered valid and fulfills the goals of Shari'ah as stipulated by certain conditions stated in the Al-Qur'an and the Hadiths. For instance, a husband/father is responsible towards his family members, beginning with the dowry (for his wife) on being married. This responsibility carries on for providing shelter, clothing, maintenance and food to sustain their daily life, in addition to other spiritual aspects. At the same time, he also retains the right to gain appreciation and full respect from his family members. In the fulfillment of these conditions, the goals of Shari'ah (welfare, benefit and happiness) become enshrined.

\section{IMPLICATION OF RIGHTS AND RESPONSIBILITIES IN ISLAM}

The execution or omission of the rights and responsibilities as outlined in Maqasid Shari'ah will have major implications on a servant of Allah's life and in the hereafter. Imam al-Shatibi stressed in his Magnum Opus al-Muwafaqat, the Maqasid/objective of Shari'ah can be reviewed in two parts - first, the objective that refers to the Creator of Law (al-Shaari') and the objective that refers to a responsible servant (al-Mukallaf) and second, the servant's objective must be in line with the limitations stated by the Shari'ah and not according to their own desires (Al-Shatibi, 2006).

Imam al-Shatibi also noted the responsibilities (al-Taklif), as commanded by the Shari'ah, also refer to the perpetuation of the objectives of the responsibilities themselves. There are three parts: 1) Dharuriyyah (essential), 2) Hajiyyah (complementary), and 3) Tahsiniyyah (embellishment). The essential (Daruriyyat) is necessary because they are indispensable in sustaining and preserving the five objectives of Shari'ah, in the sense that if they are disrupted, the stability of the society will be at stake. The complementary Maslahah are so called because they are needed in order to remove hardship and impediments and hence complement the essential interests (Dusuki, 2008).

The study focuses on the Dharuriyyat aspect only as pertaining to its relationship with the rights and responsibility of a servant. Dharuriyyat means a command on which the lives of people depend and whose neglect leads to total disruption and chaos (Kamali, 2000). Clearly, Dharuriyyat must be followed due to its continuous benefits of worldly life and the hereafter. Failure of its compliance may cause corruption and crime in the worldly

life and eternal remorse in the day of judgement. The preservation of Dharuriyyat is evident in every aspect of Shari'ah - ibadah (worship), munakahat (marriage), and muamalat (transaction). Al-Taklif (realization of rights and responsibilities) is abided by a performance of rights and responsibilities. At one side, it also abides by the avoidance of something disarray or makes it non-existent. This can include all sorts of Jinayat (criminology) (AlShatibi, 2006). 
Muamalat (Islamic financial transaction) applies to the preservation of the objective of welfare, especially in trading or in a sale and purchase. The contracting parties (al-Mukallaf) must adhere to all the pillars and conditions stated by the Shari'ah. The compliance to Dharuriyyat of the Maqasid Shari'ah will fulfill the performance of all rights and responsibilities and avoidance of criminology. As mentioned earlier, the elaboration on Maqasid Shari'ah will be incomplete without the clarification of the pillars, conditions, rights and responsibilities of the contracting parties in the context of the seller and buyer.

\section{IMPLEMENTATION OF MAQASID SHARI'AH BY CONTRACTING PARTIES IN THE BBA AND MM ISLAMIC HOUSE FINANCING}

This section discusses all related aspects of a contract, highlighting the supposed rights and responsibilities that must be performed by the seller (bank) and buyer (customer). The elaboration is supported by the Shari'ah and legal evidences.

\section{THE CONCEPT OF SALE AND PURCHASE IN ISLAM}

\section{Contracts in Islamic Law}

Until the $19^{\text {th }}$ century, no definition of contract can to be found in the treatises of Islamic law since at that point, Islamic law had yet to develop a general theory of contract. Instead, the overwhelming majority of Muslim jurists focused on the contract of sale which they regarded as the model for all contracts. However, the Islamic Civil Law Codification which took place in the $19^{\text {th }}$ century; namely, both the Majallah al-Ahkam al-'Adliyyah and Murshid al-Hayran (the 1891 Egyptian version of the Ottoman's Majallah), began to give a precise definition to a contract. The Majallah, for instance, describes contract as 'parties obligating themselves with regard to a given matter and binding themselves together with the same, as connecting an offer with an acceptance'. Also according to the Majallah, "contracting is the connection of an offer with an acceptance in a lawful manner which marks its effect on the subject of the connection" (Islamic World-Net, 2010).

The Arabic word for contract is 'Aqd (Mohammed, 1988). 'Aqd literally means tying tightly, as tying a rope. 'Aqd carries the meanings of covenant and fulfillment which can be found in the Al-Qur'an (Yusof Ali, 2008):

O ye who believe! Fulfill (all) obligations. Lawful unto you (for food) are all four-footed animals, with the exceptions named, but animals of the chase are forbidden while ye are in the Sacred Precincts or in pilgrim garb, for Allah doth command according to His will and plan. (Verse 5: 1)

In another verse of the Al-Qur'an, Allah commands to the faithful to keep the obligations which He had imposed on them when they embraced belief:

Fulfill the Covenant of Allah when ye have entered into it, and break not your oaths after ye have confirmed them, indeed ye have made Allah your surety, for Allah knoweth all that ye do. (Verse 16: 91)

There are many classifications of contract. Among these are contracts of security ('Uqud al Tawthiqat), partnership (Shirkah), safe custody (Wadi'ah), and those pertaining to perform a work (Wakalah and Ju'alah).

This study focuses on the contract of sale. A sale (Bai') is an exchange of one item for another. The Arabic term Bai' refers both to the activities of buying and selling (Ayub, 2007).

Allah has ordained that sales are permissible. This is mentioned in the Al-Qur'an (Yusof Ali, 2008):

Those who devour usury will not stand except as stand one whom the Evil one by his touch hath driven to madness. That is because they say: "Trade is like usury," but Allah hath permitted trade and forbidden usury. Those who after receiving direction from their Lord, desist, shall be pardoned for the past; their case is for Allah (to judge); but those who repeat (the offence) are companions of the Fire: They will abide therein (forever). (Verse 2: 275) 
Prophet Muhammad (PBUH) was asked what type of earning was the best, to which he answered, "The work of a man's own hand and every pious sale" [Hakim]. The Prophet (PBUH) also said, "A trustworthy and an honest and truthful businessman will rise up with martyrs on the Day of Resurrection." [Ibn Majah, Hakim]. He also said, "A truthful and trustworthy trader will rise up with the Prophets, the righteous and the martyrs." [al-Hamim, Tirmidhi] (Islamic Revival, 2006).

According to Ayub (2007), a contract comprises the following elements: the existence of two parties who are capable of entering into contracts; i.e., they must be mature and sane; an offer (Ijab) and acceptance (Qabul); a legal (Sharie) basis of union between the two declarations and the contractual obligations; and free from all prohibited factors. In general, Muslim jurists hold that, intrinsically, the essential elements of a contract are threefold and if these elements are not found properly, the contract is invalid These are the form; i.e., offer and acceptance (Sighah), the contracting parties ('Aqidain), and the subject matter (Ma'qud 'Alayh).

\section{Offer and Acceptance}

The form of the contract is essential. A necessary condition of a valid contract is the offer (Ijab). Ijab is defined as a declaration or a firm proposal made first with a view to creating an obligation, while the subsequent declaration, in response, is termed acceptance $(Q a b u l)$. Ijab signifies the willingness of a party to do something positive. Offer and acceptance can be conveyed in a number of ways; namely, by words, by gesture or indication, or by conduct. Whatever conveys the meaning with clarity is considered sufficient for the formation of a contract. It is all the same whether the words are explicit or implicit (Ayub, 2007).

The period between the offer and its acceptance should not be longer than what is customary. The offer should not be made conditional ( $\mathrm{Ta}^{\prime} \mathrm{liq}$ ) upon an occurrence outside the agreement. For example, the contract is invalid if a person sells his car under the stipulation that the purchaser shall not sell it again. "I will sell 'x' provided you sell it back to me should you decide to sell it" (Islamic Revival, 2006).

An offer is considered cancelled when the maker withdraws the offer, death or incapacity of one of the parties to enter into a contract, or termination of the contractual session, destruction of the subject matter and lapse of the period fixed for acceptance. If the two parties agree to enter into a contract in one meeting, each of them shall have a right to retract from it until they separate. It also means that an offer must be taken seriously. This is based on the saying of the Prophet (PBUH): "The contracting parties have the right to option (to finalize or not) until they separate" (Ayub, 2007).

\section{Parties to a Contract}

The contracting parties must be sane and able to run his own affairs, so no contract may be concluded by an insane person or a child who is not mature enough to run his affairs. The adherents to the Hanafi sect, however, do not make it a condition that the contractors reach legal age, for even a seven year old child who can understand and manage his affairs may conclude a contract. A child's ability to conclude a contract is studied by jurists through the following exhaustive partition: purely beneficial dealing would be permissible for the child, sheer harmful dealings are prohibited for the child and dealings that may result in benefit or harm of which the children may only conclude it if he understands it and with approval from the guardian when he is a minor or he approves them after reaching legal age (Al-Zuhaili, 2003).

A sale may not be concluded by one legal proxy for both parties, except for a father, a legal guardian, a judge, or a messenger from both parties, or for a marriage contract. Since the rights allocated by a contract are only valid for the parties to the contract, one individual party to the contract may not assume both sides (Al-Zuhaili, 2003).

\section{Validity of Subject Matter}

With regard to the subject matter or the object, the Islamic Contract Law (2010) stipulates that the following conditions must be satisfied: 
1. Value - The subject matter needs to be consistent with Islamic tenets; i.e., a contract involving wine, pork and military would be null and void, as these subjects have no value.

2. Existence - The subject matter needs to be in existence, e.g. a contract involving the sale or purchase of a house yet to be built would be invalid. There are, of course, two exceptions to this: salam (future delivery) and Istisna (order).

3. Ownership - The seller needs to have ownership of the object.

4. Deliverability - The seller is able to deliver the goods to the buyer. Of course this condition does not apply to certain objects, such as houses.

5. $\quad$ Specific - In this case, the subject must be clearly defined, e.g. "I will sell you one of my cars..." would be invalid as the car has not been defined.

If a nonexistent thing is sold, even with mutual consent, the sale is void according to the Shari'ah. A commodity which has not yet come into existence or is not deliverable, and the seller does not know as to when it could be delivered (like an animal that is missing or a stolen car) cannot be sold in order to avoid gharar (uncertainty) (Al-Zuhaili, 2003).

\section{Responsibilities of Contracting Parties in the Contemporary World}

Contract, in today's world, is no longer the same as in the past. Where once a verbal agreement would suffice, it is now no longer sufficient for the contracting parties. Contracts need to be written and documented, followed by small prints of exclusionary clauses to read. Allah has mentioned on the writing of transactions between parties in Surah Al-Baqarah (Yusof Ali, 2008):

O ye who believe! When ye deal with each other, in transactions involving future obligations in a fixed period of time, reduce them to writing, let a scribe write down faithfully as between the parties... (Verse 2:282)

The contracting parties may convene in one meeting. Communications technology has enabled them to conduct their agreements via online correspondence. In the past, it was unimaginable for contract to be made between parties who are remotely located from one another. Even the mode of contract has changed. For example, payments can be made through online transactions. Digital signatures generated by computers are recognized and accepted nowadays instead of what used to be strictly the original analog signatures of the person.

Be that as it may, the ethical considerations in sales, however, remain and are suitable to be practiced in the modern era. According to Al-Zuhaili (2003), there must be an avoidance of excessive profits, truthful and complete disclosure of information, ease of conduct and avoidance of swearing, even if truthful, frequent paying of charity, and documentation and witnessing of all debts.

In sale and purchase contracts involving financial institutions and the customer, such ethical considerations still apply and are crucial. Banks should not charge excessive profits that would be burdensome to the customer. There should be clarity when giving out information as not to mislead the customer. Both parties should not be too harsh in their conditions and should be reasonable. Customers, on the other hand, must comply with the terms agreed upon and not default in payment. They must give proper account of their details to prove that they are credible customers. Furthermore, the documentation of the transaction must be properly done and copies should be kept by both parties.

\section{RESPONSIBILITIES OF THE BANK AS A SELLER}

\section{Using Halal Capital and Products}

Under the Shari'ah, the bank must ensure that capital utilized and the products for the customers are free from all elements of riba' (usury), gharar (uncertainty), and maisir (gambling). According to Imam al-Ghazali (RA), "A Muslim who makes up his mind to adopt trade as a profession or to set up his own business should first acquire a thorough understanding of the rules of business transactions codified in the Islamic Shari'ah. Without such understanding, he will go astray and fall into serious lapses, making his earning unlawful" (Islamic Revival, 2006). 
Thus, it is pertinent for the banks to ensure that the Islamic financial products and services offered to the customers are in compliance with the Shari'ah.

Part II of the Islamic Banking Act 1983 mentions the need for advice of Shari'ah Advisory Council on matters relating to the banking business, which include the products, processes and operations. Bank Negara Malaysia (BNM), being the Central Bank, has produced several laws, policies and guidelines for Islamic Financial Institutions (IFIs) to ensure their operations and products adhere to the Shari'ah principles and requirements. One of its guideline for the IFIs is to observe the requirement of GPS-I - "Guidelines on the Governance of Shari'ah Committee for Islamic Financial Institution" issued on December 2004. To monitor the Shari'ah Committee of the IFIs, BNM had established their own Shari'ah Advisory Council (SAC) which consists of prominent Shari'ah scholars, jurists and market practitioners. SAC members are qualified individuals who can present Shari'ah opinions and have vast experience in banking, finance, economics, law and the application of Shari'ah, particularly in the areas of Islamic economics and finance. In executing its duties and responsibilities, SAC examines and endorses the validity of application of Shari'ah in Islamic financial products that are submitted by IFIs. This is indeed a good due diligence and monitoring tool in ensuring that the products are Shari'ah compliant. Concurrently, banks should not merely rely on the Council, but must also be equipped with the knowledge of Shari'ah. This is fulfilled by establishing a dedicated unit on the Shari'ah. One key factor to note is that not only the facilities and products offered should be Islamic, the source and investment of the capital itself should never contradict the Shari'ah.

A Shari'ah compliant contract must be free from riba'. Riba' is an increase in the principle that has no corresponding consideration in exchange of an asset for another asset. The increase without corresponding consideration could be either in exchange or loan transaction (Ayub, 2007). The prohibition of riba can be found in the Al-Qur'an (Yusof Ali, 2008):

Those who devour usury will not stand except as stand one whom the Evil one by his touch hath driven to madness. That is because they say: "Trade is like usury," but Allah hath permitted trade and forbidden usury. Those who after receiving direction from their Lord, desist, shall be pardoned for the past; their case is for Allah (to judge); but those who repeat (the offence) are companions of the Fire: They will abide therein (for ever). (Verse 2: 275)

There are many proofs of the prohibition of riba' in the Sunnah of Prophet Muhammad (PBUH). Notable among them is the Hadith: 'Avoid the seven grave sins...', within which the Prophet (PBUH) mentioned against devouring riba' (narrated by Muslim). Also, 'Ibn Mas'ud narrated that "the Messenger of Allah (PBUH) cursed the one who devours riba', the one who pays it, the one who witnesses it and the one who documents it" (Al-Zuhaili, 2003).

Interest in a commercial bank is a form of riba' al-nasiah which is affected through deferment and increase. This follows since commercial banking operations are primarily based on borrowing and lending, with the bank's income coming from the difference between the (lower) interest rate it pays to depositors and the (higher) rate it charges its borrowers (Al-Zuhaili, 2003).

Taking excessive profits is prohibited in Islam. It is forbidden to buy and sell with any undue advantage over other traders. An example is trading in a state of ignorance of the current market prices. Abu Hurayrah (RA) related that Prophet of Allah (PBUH) said,

Do not meet the merchant on the way and enter into business transaction with him, and whoever meets him and buys from him (and in case it is done, see) that when the owner of the (merchandise) comes into the market (and finds that he has been paid a lower price) he has the option (to declare the transaction null and void). [Hadith Muslim]

Apart from the instruments and products, banks need to ensure that their capital is also free from riba', gharar and maisir. Imam Ahmad, in his Musnad, narrated on the authority of Ibn Mas'ud (RA) that the Prophet (PBUH) said:

Whenever a man earns money through forbidden means, then the spending of this money will not be blessed, charitable payments out of it will not be accepted, and whatever he leaves behind becomes his unholy sustenance in 
the hellfire. Indeed, Allah does not cleanse impurity with impurity but he cleanses impurity with the pure. The impure can never be cleansed through impurity. (Al-Zuhaili, 2003)

A moderate degree of advantage is admissible. Otherwise, all trade would cease. However, if one side takes too much advantage of the other, the sale may be deemed void. The Maliki sect scholars defined excessive disadvantages as a profit of one-third or more, since that corresponds to the rules of limited will. Therefore, a profit rate of one-third or less is considered acceptable (Al-Zuhaily, 2003). Other criteria or conditions of the subject matter that must be revised by the seller or bank are: the existence of non-defective goods, proper disclosure, clarity (avoiding misperception), caveat emptor (literally means buyer beware), and there must not be any element of coercion/fraud.

The seller or bank also has their own rights that must be accomplished by the customer. This is the repayment of the installment monthly payment without any delay if there were no shortcomings upon their regular income. As Allah the Almighty suggests in the Al-Qur'an, every debt transaction must be recorded. The Prophet of Allah (PBUH) also reminded that the delay of certain debt by the rich is a crime. This command stresses the responsibility of the buyer to be aware of their repayment of debts and loans as it is the realization of the principle of 'Adalah (justice) in an Islamic financial transaction.

\section{CRITICAL ISSUE: THE IGNORANCE OF MAQASID SHARI'AH BY CONTRACTING PARTIES}

\section{Concept of 'Iwad in Sale and Purchase}

Iwad is a basic trait of a halal or lawful sale. A sale is necessarily an exchange of value against an equitable return and compensation for the goods and services exchanged. There are three elements of 'iwad: 1) the existence of risk (ghurm), 2) work and effort (ikhtiar), and 3) liability (dhaman). As mentioned earlier, the fulfillment of the rights and responsibilities of contracting parties is very crucial and it is categorized as Dharuriyyat of Maqasid Shari'ah. As the seller of the property, the Shari'ah requires the bank to hold ownership of the property and to hold all liabilities arising including defects. This matter is equal to the Shari'ah Legal Maxims; al- Ghurm bi al-Ghunm (any risk must be followed by any reward). But the practice currently, in comparing to $\mathrm{MM}$, is that the BBA documentations demonstrate that the bank merely acts as a financier rather than seller and excludes itself of all liabilities. By ignorance of the concept of ' $i w a d$, the BBA contract is not seen as conforming to the Maqasid Shari'ah that removes hardship (raf' al-Haraj) and preventing harm (daf' al-Dharar) when the customer is forced to face the financial burden of paying the monthly installments, even before it is completed, as he has engaged in a debt contract with the bank at the outset. On the other hand, with MM, it is agreed by Muslim scholars that the product could help the people to rely less on other financing, such as BBA. The customer's share ratio would increase after each rental payment due to the periodic redemption until eventually the asset is fully owned by the customer (Mydin Meera \& Abdul Razak, 2005).

\section{Selling a House under Construction}

In this situation, there is a crucial issue that must be reviewed in the light of Maqasid Shari'ah, which is the sale and purchase of a non-existent or a house that is still under construction. In Islam, gharar (uncertainty) is a transaction that is prohibited as its existence would harm the well-being, rights and interest of contracting parties and cannot ensure satisfactory outcomes, justice, and fairness in their contractual dealing (Md. Dahlan \& Syed Abdul Kader, 2009). Md. Dahlan \& Syed Abdul Kader (2009) agree with Mydin Meera \& Abdul Razak (2005) that the customer still has to bear all risks and costs and yet keep up with the monthly installments. In addition, the customer faces hardship when he does not have the ability to claim the return of all paid monies to the developer. The issue of gharar is highlighted by Md. Dahlan \& Syed Abdul Kader (2009) when the agreement issued by the bank is insufficient and contains unpreventive measures. They also suggest that the BBA should provide for the responsibilities and duties of the Islamic bank as the owner of the house during the course of construction. Abdul Razak \& Md. Taib (2008) support this opinion and they opined that Islamic banks must also take care of the society while promoting Islamic norms and values. 


\section{CONCLUSIONS}

From the facts outlined above and the discussions that followed, we can conclude that:

1. The framework, terms and conditions, and practice of BBA highlight several critical issues, particularly the lack of perseverance of public interest, compared to MM house financing.

2. In reviewing the literature of the subject, it is clear that the implementation of Maqasid Shari'ah in Islamic house financing is still inadequate. A probable cause is the lack of understanding and hence the lack of incorporation in the subsequent contract of the rights and responsibilities of parties to the contract.

3. The level of understanding about Maqasid Shari'ah among seller/banker/practitioner is also questionable. These point to a dire need for the Shari'ah scholars and members of the Shari'ah council to intensify their focus on bringing about greater awareness and observance of Maqasid Shari'ah.

4. The Maqasid Shari'ah provides a transparent tool to resolve some of the uncertainties in devising an Islamic house financing facility, in particular the BBA, with regard to cases involving abandoned housing projects.

Clearly, further research involving deeper study and a more thorough survey on the level of understanding of Maqasid Shari'ah needs to be undertaken. The study will also need to look further at the rights and responsibilities among bankers, practitioners, and customers in participating in an Islamic house financing contract.

\section{AUTHOR INFORMATION}

Rafidah Mohd Azli is currently a lecturer in Centre of Islamic Thought and Understanding of Universiti Teknologi MARA (UiTM) Malaysia. She obtained her MAIRK (Master of Islamic Revealed Knowledge) from International Islamic University Malaysia (IIUM). Currently she is an associate fellow of Institut Kajian Zakat, UiTM.

Dr Rohana Othman is an Associate Professor in Accounting at the Faculty of Accountancy, Universiti Teknologi MARA, Malaysia. She received her Doctorate in Accounting from the International Islamic University Malaysia, Kuala Lumpur. She also holds a Bachelor of Science (BSc) in Accounting from Indiana State University, United States of America (USA) and a Master in Business Administration (specializing in Accounting) from University of Hartford, Connecticut, USA. Her current research interests include Islamic Finance, Earnings Management and Creative Accounting, Public Sector Accountability and Governance, Corporate Governance and Corporate Social Responsibility. E-mail: rohana799@salam.uitm.edu.my

Mardhiyyah Sahri is currently a lecturer in Centre for Islamic Thought and Understanding. She obtained her Master of Comparative Law (MCL) from International Islamic University Malaysia (IIUM). Prior to joining UiTM, she worked with the Centre for Foundation Studies, International Islamic University Malaysia as a law lecturer.

Nooraslinda Abdul Aris is currently a lecturer in Faculty of Accountancy of Universiti Teknologi MARA (UiTM) Malaysia. She obtained her MBA from International Islamic University Malaysia (IIUM) and professional qualification (ACCA) from MARA Polytech College, Kuala Lumpur. Prior joining UiTM, she worked with the industry namely Standard Chartered Bank, Syarikat Takaful Malaysia, Atracc Sdn Bhd (Shell Shared Service centre) and Caltex Oil Berhad. Noraslinda is a member of Association of Chartered Certified Accountants (ACCA) and Malaysian Institute of Accountants (MIA).

Roshayani Arshad is an Associate Professor at the Faculty of Accountancy, Universiti Teknologi MARA. She holds a PhD in accountancy from UiTM, Master of Accountancy from Glasgow University and is a graduate member of ACCA. She is currently the Head of Financial Reporting Research Centre at the Accounting Research Institute and actively involved in various research projects. Her research interests include Financial Reporting, Corporate Disclosures, Corporate Social Responsibility and Corporate Governance. She has also written several books on financial accounting and reporting.

Abdul Razak Yaakob, CMIIA, is the Principal Consultant, Business Consultancy of Islamic Banking and Finance Institute Malaysia (IBFIM). He is a Professional Member of the Institute of Internal Auditors Malaysia (IIAM) and a 
Certified Performance Management and Development Instructor of Development Dimension Internationals (DDI). He graduated from University Malaya with Business Administration (Hons.) Degree, and had attended extensive business and banking executive programmes at Insead, France (Singapore Campus); London Business School UK; Manchester Business School UK; and, Federal Reserve New York and Washington, USA. He had served Bank Islam Malaysia Berhad for 8 years at various divisions. Prior to that, he worked with Bank Negara Malaysia for 14 years.

\section{REFERENCES}

1. Islamic Banking Act 1983. www.bnm.gov.my. Retrieved on 11 June 2010.

2. BNM (2007). Guidelines on Musharakah and Mudharabah contracts for Islamic Banking Institutions. www.bnm.gov.my. Retrieved on 11 June 2010.

3. BNM (2001). Guidelines on Skim Perbankan Islam. www.bnm/gov.my. Retrieved on 11 June 2010.

4. Abdul Razak, D., \& Md. Taib, F. (2008). Consumer' Acceptance on Islamic Home Financing: Empirical evidence on Bai Bithaman Ajil (BBA) in Malaysia. IIUM International Accounting Conference IV (INTAV). Putrajaya: IIUM.

5. $\quad$ Al-Shatibi. (2006). Al-Muwafaqat fi Usul al-Shari'ah. Egypt: Dar al-hadith Vol. 1-2.

6. $\quad$ Al-Zuhaili, W. (2003). Negotiation in Islam. Network Newsletter, PIN Points .

7. Ayub, M. (2007). Understanding islamic Finance. Lavoisier.

8. Dusuki, A. W. (2008). Corporate Governance and Stakeholder Management: As Islamic Perspective. International Shari'ah Research Academy for Islamic Finance (ISRA) .

9. Dusuki, A. W. (2008). What Does Islam Say About Corporate Social responsibility? Review of Islamic Economics Vol. 12. No. 1 .

10. Kamali, M. H. (2008). Maqasid al-Shari'ah Made Simple. International Institute of Islam Thought .

11. Kamali, M. H. (2002). Issues in Legal Theory of Usul and Prospects for Reform. Kuala Lumpur, Malaysia: IIUM.

12. Kamali, M. H. (2000). Principles of Islamic Jurisprudence. Kuala Lumpur, Malaysia.

13. Md. Dahlan, N. H., \& Syed Abdul Kader, S. Z. (2009). Shari'ah and Legal Issues in Housing Buying in Malaysia: The Legality of Bay' Bithaman al-Ajil (BBA) in the Light of Abonden Projects. Prosiding Muzakarah Penasihat Shari'ah Kewangan Islam. Kuala Lumpur: CERT Publications Sdn Bhd.

14. Mohamed, N. (1988). Principles of Islamic Contract Law. Journal of Law and religion, 115.

15. Mydin Meera, A. K., \& Abdul Razak, D. (2005). Islamic Home Financing through Musharakah Mutanaqisah and al_Bay' Bithaman Ajil Contracts: A Comparative Study. Review of Islamic Economic.

16. Yusof 'Ali, '. (2008). The Holy Qur'an Original Arabic text with English Translation \& Selected Commentaries . Kuala Lumpur: Saba Islamic Media Sdn Bhd.

17. McDonald. L. M. (2008). Corporate Social Responsibility and Bank Customer Satisfaction.

18. International Centre for Education Islamic Finance (INCEIF) (2007). The Application of Bay' Bithaman Ajil. INCEIF CIFP Module on Applied Shari'ah in Financial Transaction. 


\section{NOTES}

